logos_i_ethos_2013_1_(34), s. 7-29

Maciej Zarych

\title{
Cel czy tylko środek? \\ O relacjach międzyludzkich w filozofii św. Augustyna
}

Przyzwyczajeni jesteśmy do traktowania naszych relacji z bliźnimi jako najistotniejszych składników naszego życia. Przyjaźń, miłość, poszanowanie godności drugiej osoby wydają się podstawowymi elementami, na których zbudowane są systemy moralne i prawne. Zupełnie zrozumiałe wydaje się to, że większość ludzi przykłada do nich dużą wagę i zdecydowanie odróżnia sposób, w jaki należy odnosić się do ludzi, od sposobu, w jaki odnosimy się do innych bytów. Filozofia i psychologia posługują się pojęciem osoby, aby opisać tę różnicę. Porównywanie człowieka do rzeczy budzi zatem wiele kontrowersji. Człowiek nie jest takim samym bytem, jak drzewo, kamień czy komputer, na którym piszemy. Nie powinniśmy rozpatrywać go wyłącznie w kategoriach właściwości (takich jak: kolor, kształt, waga itp.), jakie przysługują wszystkim bytom. Myślę, że Kantowskie sformułowanie, które mówi o tym, że człowieka nie można traktować „tylko jako środek"1 do jakiegokolwiek, choćby najwyższego celu, można traktować jako wzorzec wyznaczający późniejsze nowożytne i współczesne rozumienie pojęcia osoby². Rzeczy mogą być tylko i wyłącznie środkami do innych celów, a ludzie już nie.

I. Kant, Uzasadnienie metafizyki moralności, tłum. M. Wartenberg, Warszawa 1971, s. 62. Pełne sformułowanie: „Postępuj tak, byś człowieczeństwa tak w twej osobie, jako też w osobie każdego innego używał zawsze zarazem jako celu, nigdy tylko jako środka”.

2 Co nie oznacza, że jest to warunek wystarczający do zdefiniowania i opisania tego, kim jest osoba. 
Św. Augustyn w tekście, który zamierzam analizować (O nauce chrześcijańskiej), posługuje się pojęciem rzeczy w odniesieniu do wszystkich bytów, do wszystkiego, o czym można orzekać: „co bowiem nie jest żadną rzeczą, jest zgoła niczym"3. Biskup Hippony pozostaje w tym miejscu całkowicie w perspektywie filozofii zorientowanej przede wszystkim na byt, z jasnym podziałem na podmiot i przedmiot. Niemniej, co oczywiste, dostrzega różnicę między ludźmi a pozostałymi rzeczami. Ludziom przysługuje specjalne miejsce $\mathrm{w}$ hierarchii stworzenia. To, że używa w stosunku do nich określenia „rzeczy” można interpretować tylko jako kwestię nazwy. Chciałbym przyjrzeć się temu zagadnieniu i spróbować zastanowić się nad tym, czy tak jest naprawdę. Interesuje mnie określenie, jaki jest stosunek w filozofii św. Augustyna do tej specjalnej rzeczy, jaką jest człowiek. Czy jest on dla Doktora Łaski zawsze celem, a nigdy tylko środkiem? Czy też może przeciwnie - człowiek zawsze pozostaje dla niego tylko środkiem w dążeniu do Boga? Wydaje mi się, że mimo szczególnego miejsca, jakie istota obdarzona duszą nieśmiertelną zajmuje w myśli Augustyna, to jego rozumienie tego, czym jesteśmy, znacznie różni się od nowożytnego i współczesnego rozumienia osoby ludzkiej. Co więcej, różni się w sposób, który z punktu widzenia filozofii współczesnej (np. filozofii dialogu) jest nie do zaakceptowania i wyznacza być może bardzo ważną różnicę w postrzeganiu świata przez ojców Kościoła i ludzi współczesnych.

\section{$U t i$ i frui - dwie relacje i dwa rodzaje rzeczy}

Zasadniczy podział na dwa rodzaje rzeczy istnieje w całej filozofii św. Augustyna. Pojawia się w różnej formie we wszystkich jego pracach. Wybrałem De doctrina christiana, ponieważ sadzę, że w nim w sposób najbardziej bezpośredni zostało wyłożone jego znaczenie. Podział dokonany jest poprzez określenie dwóch sposobów, w jaki wola ludzka może się odnosić do tego, co napotyka. Augustyn wyróżnia dwie kategorie:

3 Św. Augustyn, O nauce chrześcijańskiej, [w:] tenże, O nauce chrześcijańskiej. Sprostowania, tłum. J. Sulowski, Warszawa 1979, s. 22. 
frui i uti ${ }^{4}$. W tłumaczeniu interesującego mnie tekstu, tłumacz - Jan Sulowski - zdecydował się na oddanie tych dwóch terminów poprzez polskie: „używać” (frui) i „korzystać” (uti). To tłumaczenie jest mocno krytykowane, i jest to moim zdaniem krytyka słuszna (trzeba odnotować, że tłumacz w przypisach deklaruje, że zdaje sobie sprawę z braków swojej pracy). Łacińskie słowa są bardzo bliskoznaczne. Oba oznaczają jakiś rodzaj używania rzeczy. Augustyn wprowadza termin frui na określenie stosunku do rzeczy, który ma na celu ją samą i szczęście, które płynie z jej użytkowania lub posiadania. Natomiast uti oznacza taką relację do bytów, która ma na celu coś trzeciego. W tym wypadku chodzi o takie wykorzystanie danej rzeczy, żeby osiągnąć jakąś inną.

Zaproponowane thumaczenie moim zdaniem zupełnie zaciera tę kluczową dla Augustyna różnicę. Dochodzi w nim zresztą do dziwnego sformułowania, według którego „należy używać Boga”. Myślę, że lepsze określenia zostały dobrane np. w tłumaczeniu książki Étienne’a Gilsona ${ }^{5}$, mówi się tam o „napawaniu się" rzeczami (odpowiednik frui) i ich „używaniu” (odpowiednik uti). Taki dobór słów również nie jest doskonały. Tym razem mamy niefrasobliwie brzmiące zdanie: „napawanie się Bogiem". Mimo to uważam, że jest to propozycja zdecydowanie lepsza. Znacznie lepiej została w nim oddana podstawowa intencja stojąca u podstaw podziału: frui („napawanie się rzeczami”) - wola nakierowuje się na byt, który ma wartość sam w sobie, a pozostawanie w relacji do niego jest źródłem szczęścia. Uti („używanie rzeczy”) - wola skierowana jest ku rzeczom, które mają wartość tylko ze względu na coś trzeciego. Korzystamy z nich jak z narzędzi, które mają nas doprowadzić do prawdziwego celu. W takim tłumaczeniu zdecydowanie lepiej widać różnicę między tymi dwoma terminami. W interpretacji Sulowskiego trudno właściwie zrozumieć, czym te dwie kategorie miałyby się od siebie odróżniać. Ja w swoim tekście jeśli nie będę używał terminów łacińskich, to będę się posługiwał parą „napawać się" (frui) i „używać” (uti).

Por. tamże.

5 Por. E. Gilson, Wprowadzenie do nauki św. Augustyna, tłum. Z. Jakimiak, Warszawa 1953, s. 221. 


\section{Antropologia Augustyna}

Powyższy podział funkcjonuje w całej filozofii św. Augustyna. Pojawia się $\mathrm{w}$ różnych postaciach. Jest ściśle związany $\mathrm{z}$ antropologicznymi i metafizycznymi założeniami Biskupa z Hippony.

Podstawowym założeniem antropologicznym jest zakładanie nieusuwalnego, najważniejszego i obecnego u wszystkich ludzi pragnienia: chęci bycia szczęśliwym. Wszyscy ludzie pragną być szczęśliwi, pragną tego, co dla nich dobre, boją się cierpienia i tego, co je powoduje. Jest typowe dla całej filozofii starożytnej. Co najmniej od Sokratesa filozofowie, zgadzając się co do tego, że wszyscy pragną być szczęśliwi i nie chcą być nieszczęśliwi, starają się odpowiedzieć na pytanie, co czyni człowieka szczęśliwym. Tak samo postępuje św. Augustyn. Przyjmuje on za niepodważalny pewnik to, że u podstaw wszystkich ludzkich działań jest to podstawowe dążenie. Dlatego, co zrozumiałe, kluczowym pytaniem staje się pytanie o to, co jest w stanie uczynić człowieka szczęśliwym. Pełnia szczęścia jest nieosiągalna w tym świecie. Wszystkie przedmioty, które istnieją w świecie, są niedoskonałe i przemijają. Dlatego życiu towarzyszy stale lęk i poczucie niespełnienia.

Kiedy nie mamy jakiegoś dobra, odczuwamy brak. Kiedy je osiągamy, lękamy się go utracić, i wreszcie ono samo, jak wszystko, co podlega czasowi, musi przeminąć. Człowiek zostaje wtedy znów z poczuciem braku i niezaspokojonego pragnienia. Tylko dobro doskonałe, a więc niepodlegające przemijaniu, mogłoby zaspokoić potrzebę pełni i szczęścia. Takie postrzeganie zarówno pragnienia, jak i wartościowanie stawiające to, co stałe i niezmienne, wyżej tego, co zmienne i podlegające czasowi, również jest dziedzictwem myśli starożytnej. To, co stałe i niezmienne, jest lepsze od tego, co zmienne; to, co niezmienne, jest też wieczne, bo inaczej nie byłoby niezmienne, a więc lepsze od tego, co przemija i jest śmiertelne. Następnie to, co doskonałe, musi być niezmienne i wolne od pragnień, bo inaczej w grę wchodziłby jakiś brak. Prawda jest stała, wieczna i niezmienna, utożsamiana z Dobrem. I wreszcie, tylko temu, co stałe i niezmienne, przysługuje istnienie w pełnym tego słowa znaczeniu. 
Wszystkie te założenia znajdziemy u Augustyna w dokonanej przez niego ich chrześcijańskiej reinterpretacji. Bóg jest utożsamiany z tym, co stałe i niezmienne. Tylko Bogu przysługuje w pełni istnienie (wszystko inne zawdzięcza swoje bytowanie Absolutowi). Jest On wreszcie utożsamiany z Prawdą i Dobrem; jest doskonały, posiada pełnię, niczego $\mathrm{Mu}$ nie brak. Tylko Absolut i nakierowanie swojego życia na Niego może uczynić człowieka szczęśliwym.

Pojawia się tutaj kolejny istotny element sposobu myślenia św. Augustyna. Człowiek „upodabnia” się do tego, co jest przedmiotem jego dążenia. Dusza w jakiś sposób staje się tym, w czym upatruje swoje dobro. Nie chodzi tutaj oczywiście o zmianę ontologicznego statusu duszy. Dusza nie przestaje być substancją myślącą, niematerialną, nierozciągłą, stworzoną, ale nieśmiertelną. Chodzi o związek innego rodzaju. U Augustyna człowiek przynależy do tego, czego pragnie. H. Arendt w swojej pracy doktorskiej opisywała to w następujący sposób:

Człowiek jest tym, co stara się osiągnąć. Miłość pośredniczy między tym, który kocha, i tym, co jest kochane, a ten, który kocha, nie jest nigdy oddzielony od tego, co kocha, przynależy do niego. Pożądanie tego, co jest z porządku świata jest światowe, przynależy do świata. Ten, który pożąda, decyduje o swoim upadku przez samo swoje pożądanie, podczas gdy miłosierdzie, ponieważ pragnie wieczności, staje się samo wieczne $e^{6}$.

W ten sposób kluczowe znaczenie w filozofii św. Augustyna ma „nakierowanie” duszy. Dusza, która w świecie szuka szczęścia upodabnia się do świata. Dobra, których pragnie, są niestałe, zmienne i śmiertelne, tak więc dusza również przeżywa zmiany, załamania i ciągłe niedające się zaspokoić poczucie braku. Człowiek, który w nich chciałby zaznać pełni angażuje się $\mathrm{w}$ rzeczy $\mathrm{z}$ definicji skazane na śmierć i przemijanie. W ten sposób cierpi podwójnie: nie mogąc nigdy zaspokoić pragnienia i przeżywając każdą nieuniknioną stratę. Z kolei człowiek, który w stałym, niezmiennym Absolucie szuka swojego zaspokojenia, może, jeśli 
na to zasłuży, je osiągnąć. Bóg nigdy nie przeminie, nie zniknie i nie porzuci tego, kto pozostanie Mu wierny. Decyzja należy jednak do człowieka i ona przesądza o jego losie (kwestię grzechu pierworodnego i łaski świadomie zostawiam).

$\mathrm{Z}$ „ukierunkowaniem” duszy związane jest kolejne zagadnienie, a mianowicie hierarchia bytów. Otóż świat ma strukturę pionową. $\mathrm{Na}$ samym szczycie jest Bóg. Doskonały, samowystarczalny, niezmienny i dobry. Później - byty przebywające w jego pobliżu. Aniołowie, święci i apostołowie oraz ludzie, którzy zostali zbawieni. Choć stworzeni, to dzięki dobrej woli, która pozwala im stale przebywać w pobliżu Boga, mogą cieszyć się szczęśliwym życiem wiecznym. Następnie są dusze ludzkie, stworzone, ale nieśmiertelne, istniejące w stojących niżej od nich ciałach i niżej od nich stojącym świecie materialnym. Na czele świata materialnego jest człowiek. W człowieku wyżej stoi dusza niż ciało. Dusza ma za zadanie kierować ciałem. Na ostatnim miejscu są inne byty: zwierzęta i przedmioty materialne ${ }^{7}$.

Po nakreśleniu tej zasadniczej dla Augustyna hierarchii można znowu wrócić do zagadnienia „ukierunkowania” duszy. Dusza może wybrać kierunek „ku górze” a więc ku Bogu, ku transcendencji, ku powiększaniu swojego uczestnictwa w istnieniu. Kiedy tak czyni, to może z woli Boga i dzięki Jego łasce zostać zbawiona i doświadczyć prawdziwego szczęścia. Alternatywą dla tego jest życie światowe. Wybieranie tego, co jest niżej w hierarchii w poszukiwaniu złudnego szczęścia. Dóbr materialnych, przyjemności oferowanych przez świat albo samego siebie. Człowiek, wybierając coś innego niż Bóg, popełnia grzech, stawiając to (a w ostatecznym rozrachunku siebie - ponieważ pycha jest źródłem wszelkiego grzechu) ponad swojego Stwórcę. Wybierając coś innego niż Bóg, a więc coś stojącego poniżej Niego w hierarchii, człowiek kieruje się „ku dołowi” i zamiast powiększać swój udział $\mathrm{w}$ istnieniu, pomniejsza go.

Oczywiście również idea zhierarchizowanego porządku bytów, „łańcucha bytów” nie jest wyłączną koncepcją Augustyna. Była ona obecna w kulturze europejskiej od starożytności aż do czasów nowożytnych. Por. A. O. Lovejoy, Wielki łańcuch bytu, tłum. A. Przybysławski, Warszawa 1999. 
Stwierdziliśmy zaś, że wybór przedmiotu należy do woli i że tylko wola może złożyć z tronu pierwiastek rozumny i uniemożliwić jego prawidłowe działanie. Wykazaliśmy wreszcie, że trzeba obwiniać człowieka, który robi zły użytek z rzeczy, a nie rzecz samą [...]. Zgadzam się, że wszystkie grzechy zawierają się w tym jednym rodzaju zła: $\mathrm{W}$ odwróceniu się od dóbr boskich, prawdziwie trwałych, ku zmiennym i niepewnym ${ }^{8}$.

Zło to brak dobra, to odwrócenie porządku w hierarchii. Wszystko, co stworzone, jest dobre. Przedmioty same w sobie są dobre, bo są dziełem dobrego Boga. To dopiero akt woli ludzkiej może wprowadzić do świata dobro albo zło. Odwracając słuszną hierarchię i wybierając świat w miejsce Boga, człowiek jest twórcą zła. A zło nie ma substancjalnej treści, bo jest jedynie negacją. Odwróceniem się stworzenia od swojego Stworzyciela i ukierunkowaniem się w stronę nicości, zamiast w stronę istnienia. W ostatecznym rozrachunku zło to brak, pustka i nicość, bo takie są konsekwencje powierzenia swojego życia temu, co przemija i jest śmiertelne.

Jedynym wyjściem jest nakierowanie swojej woli na Absolut i uznanie, że wszystko, co istnieje, istnieje jedynie ze względu na Niego i po to, żeby do Niego prowadzić. Warto tutaj podkreślić dwie rzeczy. Po pierwsze, taki podział na dwie kategorie bytów nie jest wyłącznie neutralną klasyfikacją metafizyczną. Dokonany jest poprzez określenie relacji woli do rzeczy (a więc nie jest to prosta „cecha” albo „właściwość” danego bytu w rodzaju wagi, kształtu, koloru itp.) i ma od początku moralny charakter. Porządek metafizyczny jest jednocześnie porządkiem moralnym świata. Po drugie, w ostatecznym rozrachunku podział na uti i frui jest tożsamy z podziałem na miłość do świata i miłość do Boga, a jedynym bytem, z którym powinno się pozostawać w relacji frui, jest Bóg.

O ile jednak przeciwstawiamy sobie miłość do Boga i do świata, przez świat rozumiejąc dobra materialne - zmysłowe przyjemności itp., to teza ta wydaje się stosunkowo niekontrowersyjna. Absolut stoi wyżej niż wszystkie dobra i przyjemności świata ziemskiego. Konsekwencją 
jednak tak skonstruowanego systemu jest to, że do miłości światowych (a więc do napawania się niewłaściwymi rzeczami) wypada także zaliczyć, przynajmniej w znacznym stopniu, ludzi. Jaki zatem jest postulowany przez Ojca Kościoła stosunek człowieka do swoich bliźnich?

\section{Człowiek jako środek do wyższego celu}

System św. Augustyna jest skrajnie teocentryczny. Bóg zajmuje w nim najważniejsze miejsce. Jest celem wszystkich dążeń i wszystkich działań ludzkich. Jedyną wartością samą w sobie. Prawidłowa relacja do Niego to relacja frui - napawania się. Chciałbym w tym miejscu zasygnalizować i pozostawić nierozstrzygniętym pytanie o to, czy również wiara nie jest środkiem do osiągnięcia najbardziej podstawowego celu - bycia szczęśliwym. Gdyby tak było, to nawet Boga nie można byłoby uznać za wartość samoistną (bo tak naprawdę nic nie mogłoby nią być), a Augustynowi trzeba by było wykazać niekonsekwencje. Problem ten prowadzi do szerszego zagadnienia, dotyczącego charakteru etyk eudajmonistycznych w starożytności. Skoro większość z nich przyjmowała za podstawowy aksjomat i jednocześnie ostateczny cel pragnienie bycia szczęśliwym, to można zarzucić im, że pojęcie dobra jako celu samego w sobie było właściwie nieznane. Każde dobro, czy materialne, czy duchowe, w ostatecznym rozrachunku miało czynić szczęśliwym. Egoistyczne pragnienie własnej pomyślności było motywem wszelkich dążeń.

Odpowiedź na to pytanie wymagałaby rozważenia tego, jak rozumiano pojęcie szczęścia. Czy było ono równoznaczne z naszymi nowożytnymi i współczesnymi wyobrażeniami? Czy chodziło tylko o uczucie przyjemności, satysfakcji i zaspokojenia? Czy może starożytna kategoria bliższa była raczej temu, co my moglibyśmy nazwać dobrym życiem w znaczeniu życia przeżytego zgodnie z moralnymi wyznacznikami i słusznym porządkiem ogólnym? Nie podejmuję się rozstrzygać tutaj tego złożonego zagadnienia. Chciałem tylko zasygnalizować, że problem dotyczy również filozofii Biskupa Hippony. Na potrzeby tego tekstu przyjmuje - w zgodzie z tym, co deklaruje Augustyn - że faktycznie Bóg jest dla niego wartością samą w sobie. 
Po tych założeniach zagadnienia, które mnie interesują, wyglądają następująco: jaki jest prawidłowy stosunek ludzi do swoich bliźnich - frui czy uti? I w związku z tym, jak to się ma do traktowania każdego człowieka jako autonomicznej osoby, której nie można traktować tylko jako środka do innego celu?

Augustyn przynajmniej częściowo dostrzegał te problemy i sformułował je w następujący sposób:

Tu nasuwa się ważne pytanie, czy ludzie siebie nawzajem powinni używać [frui - napawać się], czy korzystać [uti - używać] lub też i jedno, i drugie? Przykazano nam, byśmy się nawzajem miłowali, lecz zachodzi pytanie, czy człowieka należy miłować ze względu na niego samego, czy na coś innego? Jeśli ze względu na niego, to go używamy [frui - napawamy się], jeżeli coś innego, to zeń korzystamy [uti - używamy go $]^{9}$.

Doktor Kościoła daje w zasadzie jasną odpowiedź na tak postawione zagadnienie:

Zważywszy rzecz należycie, nawet siebie samego nikt nie powinien używać [frui - napawać się] ponieważ i siebie samego nie powinno miłować się ze względu na siebie, ale dla Tego, którego mamy używać [frui - napawać się] [...]. Jeżeli więc nawet siebie samego powinieneś miłować nie ze względu na siebie samego, ale na Tego, w którym znajduje się najwłaściwszy cel twojej miłości, to inny człowiek niech się nie obrusza, że i jego miłujesz ze względu na Boga. Bo przez Boga zostało ustanowione przykazanie miłości: będziesz miłował - powiada - swego bliźniego jak siebie samego, natomiast Boga, całym sercem, całą duszą, całym umysłem. Abyś wszystkie swoje myśli, całe życie, całą duszę kierował ku Temu, od którego masz to, co posiadasz [...]. Ktokolwiek więc należycie miłuje bliźniego, powinien wobec niego tak postępować, by i tamten miłował Boga całym sercem, całą duszą i całym umysłem. Miłując go bowiem, jak siebie samego, całą miłość siebie i bliźniego, kieruje ku tej miłości Boga, która nie zezwoli, aby jakikolwiek strumyk oddzielił się od niej, pomniejszając ją ${ }^{10}$.

9 Św. Augustyn, O nauce chrześcijańskiej, dz. cyt., s. 28.

10 Tamże, s. 29. 
Umyślnie zdecydowałem się przytoczyć tak obszerne cytaty. Dają one doskonały wgląd zarówno w to trudne zagadnienie, jak i w sedno sposobu myślenia Augustyna.

Dylemat, przed którym staje Biskup Hippony, dobrze ilustruje przytoczenie przykazania miłości. Składa się ono z dwóch członów. W pierwszym nakazuje się miłość do Boga ponad wszystko. Podstawowy obowiązek chrześcijan. Cecha charakterystyczna religii monoteistycznej - Absolut zajmuje pierwsze, niepodzielne miejsce w hierarchii wartości. Drugi człon to nakaz miłości bliźniego. Docelowo ma być on równy najbardziej zapewne instynktownej miłości własnej. Pomiędzy tymi dwoma elementami nauki chrześcijańskiej może dochodzić do konfliktów. Który z nich jest ważniejszy? Jeśli przyznać, że pierwszy, to jak w takim razie ma wyglądać miłość do ludzi, skoro ponad wszystko uwielbiony ma być Bóg? Nie są to bynajmniej tylko teoretyczne zagadnienia, z którymi borykają się akademiccy filozofowie. Wydaje mi się, że mamy tu do czynienia $\mathrm{z}$ jednym $\mathrm{z}$ najciekawszych dylematów związanych $\mathrm{z}$ doświadczeniem religijnym. Praktyczne pytania, przed którymi staje człowiek zastanawiający się nad swoją wiarą i jej najważniejszym przykazaniem, mogą dotyczyć tego, jak właściwie powinien się ustosunkować do swojego bliźniego? Kim jest dla mnie mój przyjaciel? Kim jest dla mnie moja żona, mąż albo dziecko? Czy czasem nie jest tak, że kiedy naprawdę badam swoje myśli i uczucia, to są oni dla mnie ważniejsi nawet od wiary? Czy takie porównania i przeciwstawienia mają w ogóle sens? Czy ma sens odmierzanie i hierarchizowanie stopnia zaangażowania?

Augustyn stara się rozwiązać ten potencjalny konflikt w zgodzie ze swoją doktryną. Jedynym właściwym celem staje się Bóg. Tylko Nim można się napawać. Wszystkie pozostałe byty są tylko środkami do założonego celu. To rozwiązanie radykalne. Nasze relacje z innymi ludźmi są instrumentalizowane. Mają wartość o tyle, o ile ich ostatecznym celem nie jest dana osoba - tylko Absolut. W ten sposób Biskup Hippony określa, w jaki sposób czyny są dobre albo złe. Decyduje akt woli. Jeżeli wola zwraca się do rzeczy ziemskich, w tym do swoich bliźnich, mając na celu je same, to wtedy mamy do czynienia ze złem moralnym. Jakkolwiek mogłoby nam się inaczej wydawać, jest to wywrócenie słusznej hierarchii. 
Ciekawą ilustracją tej konsekwencji myśli Augustyna jest księga IV Wyznań. Pojawia się tam opis śmierci przyjaciela. Obserwujemy silne emocje przeżywane przez późniejszego Doktora Kościoła. Rozpacz po utracie bliskiego wskazuje, jak duże było zaangażowanie Augustyna w tę relację. Cały jednak opis przytaczany jest w zupełnie innym celu. Chodzi o to, aby pokazać znikomość wszystkich rzeczy związanych z tym światem. Pełne zaangażowanie, nawet w coś zdawałoby się tak wzniosłego jak przyjaźń, może prowadzić ostatecznie tylko do śmierci (ludzie są śmiertelni) i do cierpienia. Pojawia się tam również zdanie podsumowujące relację ze zmarłym:

Razem dorastaliśmy, razem chodziliśmy do szkoły, wspólnie się bawiliśmy. Ale i to nie była - zarówno w dzieciństwie, jak i później - taka przyjaźń, jaką można by nazwać prawdziwą ${ }^{11}$.

Biorąc pod uwagę całość myśli Augustyna, nie jest to zaskakujące. Relacja ze zmarłym przyjacielem nie była prawdziwa, ponieważ miała na celu nie Boga, tylko osobę zmarłego. Nie została zawarta, jak będzie pisał w dalszej części Wyznań, „ze względu na” Kogoś ważniejszego. Oczywiście - ze względu na Boga. Relacja istniejąca ze względu na coś innego, to, jak zresztą sam Biskup Hippony przyznaje, relacja uti - używania. Dzięki temu człowiek może uniknąć rozpaczy związanej z przemijaniem rzeczy ziemskich. Absolut nigdy nie zniknie i nigdy się nie zmieni. Nigdy też, jako Byt doskonały i dobry, nie opuści tych, którzy Mu zawierzą i będą tylko Nim się napawać. Kiedy czytamy opis reakcji Augustyna na śmierć jego matki Moniki, obserwujemy, jak wiara może chronić przed rozpaczą. Wbrew otoczeniu i nawet ku zdziwieniu swoich bliskich, Augustyn pozostaje spokojny po jej śmierci. Jest tak, ponieważ wycofuje on, przynajmniej częściowo, swoje zaangażowanie z rzeczy i osób związanych z tym światem. Zawierza Bogu i skupia się na Nim jako na jedynym celu.

Taka postawa, będąca dla Doktora Łaski najważniejszym elementem praworządnej miłości chrześcijańskiej, jest w większym stopniu 
postulatem etycznym niż opisem faktów. Oczywiste jest to, że chrześcijanie są związani emocjonalnie zarówno z dobrami materialnymi, jak i z innymi ludźmi ${ }^{12}$. Mimo iż Augustyn nie nakazuje porzucenia relacji międzyludzkich, to jednak postępowanie w myśl jego filozofii prowadzi do rewizji dotychczasowych wyobrażeń i postaw. W punkcie wyjścia jesteśmy związani ze światem, jesteśmy zaangażowani - można powiedzieć - nadmiernie. Jest to jedna z konsekwencji grzechu pierworodnego. Po upadku Adama i Ewy ludzie odwrócili się od Absolutu i szukają swojego szczęścia w rzeczach niestałych i śmiertelnych. Chcąc wypełniać przykazania i być dobrymi chrześcijanami, powinniśmy pracować nad sobą, tak żeby z pomocą Boga odwrócić to grzeszne pożądanie od świata i skierować je na jego Stwórcę. Wszystkie nasze uczynki i wszystkie nasze stosunki międzyludzkie powinny istnieć ze względu na Boga. Tak wyznaczony cel może być niewykonalny w pełni dla nikogo, lub prawie dla nikogo, ale stanowi punkt odniesienia dla każdego człowieka wierzącego.

\section{Stosunek do innych}

Analizowałem dotychczas pierwszą część przykazania miłości - miłość Boga. Teraz chciałbym przejść do jego drugiego członu - do nakazu miłości bliźniego. Chodzi o zrozumienie, jak dokładnie wg Augustyna powinny wyglądać nasze relacje z innymi ludźmi. Z nakazu uwielbienia Boga ponad wszystko i w każdym momencie wynika jasno, że więzi, jakie łączą ludzi między sobą, powinny należeć do kategorii uti - używania. Wydaje się to jednak nieintuicyjne i budzące pewne zastrzeżenia. Przykazanie nie ogranicza się przecież do nakazania miłości Boga. Chodzi również o miłość skierowaną do innych ludzi. Jak można pogodzić wycofanie z zaangażowania w świat i rzeczy ziemskie z tą najważniejszą dla chrześcijan nauką?

12 Peter Brown w biografii Augustyna pisze, że „Augustyn nigdy nie był samotny”. Przez całe życie otaczał się gronem wiernych przyjaciół, którzy razem z nim stawali się manichejczykami, a potem nawracali się na chrześcijaństwo. Zob. P. Brown, Augustyn z Hippony, tłum. W. Radwański, Warszawa 1993. 
Tak jak powiedziałem, Augustyn dostrzega ten problem. W swoich słynnym tekście Homilii na Pierwszy List św. Jana ${ }^{13}$ odwołuje się do tych fragmentów Ewangelii i nauczania apostołów, gdzie wprost dowiadujemy się, że jest rzeczą niemożliwą kochanie Boga i równoczesne niekochanie człowieka. Co więcej, człowiek jest zobowiązany nie tylko do życzliwości i dbania o swoich najbliższych. Jak wiadomo, miłość bliźniego powinna dochodzić do takiego miejsca, gdzie ludzie potrafią w równym stopniu kochać również swoich nieprzyjaciół. Wszystko to wydaje się wykluczać jedynie „użytkowanie" (uti) innych ludzi jako środka prowadzącego do Boga. W przytaczanym przeze mnie powyżej obszernym cytacie Doktor Łaski pisze o tym, że być może stosunek do człowieka powinien być zarówno uti, jak i frui. W homilii na list św. Jana pojawiają się fragmenty, gdzie Biskup Hippony naucza o tym, że bliźnich należy kochać dla nich samych, a nie dla własnego dobrego samopoczucia. Chodzi o to, żeby czyniąc dobro innym osobom, naprawdę mieć te osoby na myśli, a nie samego siebie. Jest to grzech pychy - człowiek upaja się tym, że postępuje słusznie i zasługuje na nagrodę. W niemal wszystkich pismach Ojca Kościoła, a szczególnie w tych nastawionych bardziej katechetycznie, skierowanych z pozycji nauczyciela bezpośrednio do wiernych, pojawiają się nawoływania do miłości bliźniego.

Z pewnością sprawa ta nie jest do końca jednoznaczna. W doktrynie Augustyna pojawiają się elementy, które niuansują całokształt tego zagadnienia i sugerują różne możliwe odczytania jego myśli. Gdyby przyjąć interpretację mniej krytyczną, ograniczającą nieco radykalizm Augustyna, to można by powiedzieć, że wzajemny stosunek ludzi do siebie jest zarówno $u t i$, jak i frui. Mielibyśmy do czynienia z napawaniem się, które można by nazwać warunkowym. Stosunek frui w pełnym tego słowa znaczeniu to stosunek do Absolutu. Niemniej po zapewnieniu Bogu pierwszego miejsca w hierarchii wartości i porządku świata pozostaje jeszcze miejsce na miłość do ludzi. Taką, której przedmiotem są faktycznie osoby, których autonomiczną wartość się uznaje - niezależnie od tego jak postępują, jak np. w miłości nieprzyjaciół.

13 Św. Augustyn, Istnieje tylko miłość. Homilie na Pierwszy List św. Jana, tłum. W. Kania, Kraków 2000. 
Sądzę jednak, że pomimo niektórych niejednoznacznych wątków pojawiających się w tekstach Biskupa Hippony bardziej przekonujące i uzasadnione z punktu widzenia całości doktryny jest bardziej radykalne odczytanie Augustyna. Stosunek frui - napawania się - należny jest jedynie Bogu. Ludzie pozostają do siebie w relacji wyłącznie uti - używania. Wyklucza to jakiekolwiek uznanie autonomicznej - niezależnej od Boga - wartości osoby ludzkiej. Wydaje mi się, że staje się to lepiej widoczne przy bliższej analizie interesujących mnie wątków.

Miłość nieprzyjaciół to niewątpliwie jeden z podstawowych nakazów etyki chrześcijańskiej. Teoretycznie można go rozumieć w taki sposób, że człowiek jest wezwany do równego stosunku - miłości - do wszystkich ludzi niezależnie od tego, co oni czynią i kim dla nas są. W interpretacji nieco bardziej zachowawczej (i bardziej wykonalnej), bliskiej być może Kantowskiemu odczytaniu tego przykazania, każdy człowiek jest wezwany do poszanowania podstawowej godności każdej osoby ludzkiej niezależnie od tego, kim by ona nie była i jak postępowała. Pomimo wszelkiego zła, na które nie wyrażamy zgody i któremu się sprzeciwiamy, widzimy w każdej osobie cel sam w sobie, a nie wyłącznie środek do wyższego celu. U św. Augustyna źródłem godności ludzi jest Bóg. W miłości nieprzyjaciół skupiamy się nie na tym, co indywidualne w danym podmiocie (to właśnie jest odpowiedzialne za złe uczynki), interesuje nas to, co najbardziej ogólne. Nawet grzesznik posiada duszę i jest dziełem Boga. Kochamy w nim to, co pochodzi od Boga, a nie to, co pochodzi od niego samego. To Bóg jest źródłem i celem naszego stosunku do nieprzyjaciół. Nie ma tutaj żadnego miejsca na wartość samoistną osoby ludzkiej. Jest to jak najbardziej relacja używania, a nie napawania się.

Także opisując w licznych przykładach to, jak wygląda chrześcijański stosunek do bliźnich, Augustyn opisuje w gruncie rzeczy relację uti.

Bo jeżeli w teatrze ktoś lubi jakiegoś aktora i raduje się jego sztuką niby wielkim, a może najwyższym dobrem, lubi też tych, którzy razem z nim go podziwiają, nie ze względu na nich, ale z powodu wspólnego przedmiotu miłości ${ }^{14}$.

14 Św. Augustyn, O nauce chrześcijańskiej, dz. cyt., s. 33. 
Tym, co łączy i podtrzymuje relacje, nie jest autentyczna wartość osoby, kogoś, kto miałby razem z całym swoim doświadczeniem życiowym znajdować się naprzeciw nas, lecz odniesienie do Absolutu. Jeśli chodzi o wspólnotę ludzi wierzących, to wspólny cel wiary: Bóg jest tym, co spaja i nadaje ludziom wartość. Jeśli chodzi o niewierzących i grzeszników, to ich godność ocala pochodzenie od Boga. Jak wiadomo, według Augustyna niezależnie od tego, jak człowiek nisko upadnie, to i tak jego dusza pozostanie nieśmiertelnym dobrem. W tym, co pozostaje w niej zawsze niezmienne i nieskażone, pochodzi od Boga. W ten sposób zawiązuje się szczególna wspólnota. Nie potrzebuje ona żadnych bezpośrednich kontaktów, by utrzymywać więzi. Wystarczy, że wszyscy obywatele tak rozumianego Państwa Bożego skupieni są na miłości Boga. Fakt zarezerwowania relacji frui jedynie dla Stwórcy powoduje, że ludzie, istniejąc w świecie, powinni ćwiczyć się w bardzo specyficznym do niego stosunku (dotyczy to także ich wzajemnych związków):

Czy słowa: „Nie kochajcie tego” znaczą, abyście nie jedli, nie pili, nie rodzili dzieci? Nie. Lecz należy zachować miarę według woli Stwórcy, aby was miłość tego nie ujarzmiła, abyście tego nie kochali dla rozkoszy, co mieć winniście dla użytku ${ }^{15}$.

Ziemskie bytowanie staje się rodzajem obowiązku, który trzeba wypełnić. Wszystko, co jest stworzone, jest dobrem, ponieważ z pewnością pełni jakąś - być może z początku niedostrzegalną - funkcję w ogólnym porządku i planie Opatrzności. Obowiązek trzeba wypełnić sumiennie i do końca (jakiekolwiek myśli o umyślnym skróceniu tego okresu przejściowego są niedopuszczalne), ale bez zbytniego zaangażowania. Pracując, modląc się, wchodząc w różnorodne związki z innymi osobami, trzeba zawsze mieć na myśli tylko jeden jedyny cel ostateczny, jakim jest Bóg.

Kolejną kwestią świadczącą przeciwko mniej radykalnemu odczytywaniu podziału na dwa rodzaje stosunku do rzeczy jest ciągłe podkreślanie absolutnego i wyłącznego charakteru miłości do Boga. Każda 
próba dzielenia zaangażowania ludzkich emocji i ludzkiej miłości na byt i jego Stworzyciela jest traktowana jako umniejszanie chwały Bożej. Gdyby nawet proporcje miały być skrajnie niesymetryczne, to i tak byłoby to zdradą wobec Absolutu. „Mniej Ciebie kocha ten, kto oprócz Ciebie kocha coś innego jeszcze, co nie ze względu na Ciebie miłuje"16. Gdyby faktycznie relacja do człowieka zaliczała się do kategorii frui, to Ojciec Kościoła musiałby dopuścić w jakimś stopniu uznanie autonomicznej wartości osoby ludzkiej - jako celu samego w sobie. Nie jest to jednak do pogodzenia $\mathrm{z}$ wymogiem niepodzielnej uwagi i oddania Bogu. H. Arendt ujęła to w następujący sposób:

W każdym konkretnym człowieku kocha się to samo źródło; wobec tego wspólnego źródła jednostka jest zbędna. Tak więc chrześcijanin może kochać wszystkich ludzi, ponieważ wszyscy są tylko okazją, pobudką, i tą okazją może być każdy ${ }^{17}$.

Wprawdzie miłość bliźniego jest nakazanym sposobem praktykowania miłości do Boga, to jednak - jak sądzę - przy bliższej analizie można mieć wątpliwości czy faktycznie mamy tu do czynienia $\mathrm{z}$ autentycznym nakierowaniem na drugą osobę.

\section{Miłość własna}

Myślę, że kluczem do zrozumienia tego, na czym polega Augustiańska interpretacja przykazania miłości ludzi, jest zrozumienie tego, jak odczytywany jest zwrot „jak siebie samego”. Przytoczę raz jeszcze fragment De doctrina christiana, który już przywoływałem na początku:

Jeżeli więc nawet siebie samego powinieneś miłować nie ze względu na siebie samego, ale na Tego, w którym znajduje się najwłaściwszy cel twojej miłości, to inny człowiek niech się nie obrusza, że i jego miłujesz ze względu na Boga ${ }^{18}$.

16 Tenże, Wyznania, dz. cyt., s. 309.

17 H. Arendt, Le concept d'amour..., dz. cyt., s. 125.

18 Św. Augustyn, O nauce chrześcijańskiej, dz. cyt., s. 29. 
Św. Augustyn uważa, że miłość własna jest czymś niezbywalnym i nieodłącznie związanym z każdym człowiekiem. Każdy z nas kocha siebie i ma na celu własne dobro. Nawet ludzie, którzy stracili chęć do życia i mówią, że woleliby nie być w ogóle, robią tak, ponieważ śmierć postrzegają jako dobro. Obecne życie jest dla nich pasmem nieszczęść, od których chcą się uwolnić. $\mathrm{Z}$ tego powodu mogą postrzegać koniec istnienia jako dobro.

Doświadczenie religijne wiąże się ze zmianą tego najbardziej naturalnego (wg Augustyna) stosunku do samego siebie. Otóż człowiek wierzący powinien w miejsce miłości własnej postawić miłość do Boga. Jest to zapewne jedno z najtrudniejszych zadań, które przed nim stoją. Siebie powinniśmy kochać o tyle tylko, o ile jesteśmy dziełem Stworzyciela. Godność każdej jednostki nie pochodzi stąd, że postrzega się ją jako autonomiczny podmiot. Warto zwrócić uwagę na to, że nakłada to na każdego człowieka wymóg obiektywizacji stosunku do samego siebie. Ideałem byłaby sytuacja, w której traktuje się samego siebie tak jak wszystkie inne przedmioty w świecie. Użytkując dobra światowe, spełniamy Boży plan wobec nas i oddajemy Mu cześć. Siebie również powinniśmy traktować $\mathrm{w}$ ten sposób. Wszystko, co w nas wartościowe i godne szacunku, pochodzi od Boga. To nie nam należy się uwaga i uznanie, tylko Jemu. Każdy powinien nabierać dystansu nawet do samego siebie. Oczywiście, jak już wspominałem, to pewien postulat, idealny cel, do którego powinno się dążyć, ale który wydaje się - przynajmniej dla większości ludzi - niewykonalny.

$\mathrm{Na}$ tę kwestię zwracał również uwagę E. Gilson:

Jeśli teraz powrócimy do zagadnienia miłości bliźniego, to stwierdzimy, że jest ono w istocie rozstrzygnięte. Człowiek powinien kochać swoje ciało dla duszy, a duszę dla Boga. [...] Augustyn dochodzi tu więc do pojęcia życia moralnego i społecznego, opartego na jednej jedynej zasadzie: człowiek cnotliwy używa wszystkiego, włącznie z samym sobą, ze względu na Boga i pragnie, żeby wszystkie istoty we wszechświecie używały tak, jak on, samych siebie tylko przez wzgląd na Boga ${ }^{19}$.

19 E. Gilson, Wprowadzenie..., dz. cyt., s. 223. 
W ten sposób można pogodzić nakaz miłości bliźniego (jak siebie samego) z wyłącznym charakterem stosunku do Absolutu. Używając innych (uti), traktujemy ich jako środki do wyższego celu. Niemniej, tak samo powinniśmy traktować samych siebie. To być może dla wielu ludzi nieco nieintuicyjne rozwiązanie, ale dzięki temu Augustynowi udaje się utrzymać skrajnie teocentryczny charakter swojego systemu. Wszyscy, my także, nabieramy jakiejkolwiek wartości jedynie poprzez stosunek do Absolutu. Wolno uznawać naszą wartość jedynie przez wzgląd na Niego.

\section{Augustyn a filozofia dialogu}

W filozofii św. Augustyna prawidłowy (tzn. określony jako wzorzec, do którego należy dążyć) stosunek ludzi do swoich bliźnich to relacja uti. Człowiek jest narzędziem, któremu wprawdzie przyznaje się wyższy status, ale jednak jedynie narzędziem w dążeniu do Absolutu. Jedynym właściwym celem jest Bóg. Jest On jedynym w świecie Augustyna bytem, któremu przysługuje wartość sama w sobie (nie „ze względu na”). Co więcej, Bóg domaga się miłości wyłącznej, pełnego zaangażowania, które nie może być w żaden sposób pomniejszane o miłość do świata. Jeśli teraz przeszlibyśmy od filozoficznych założeń do rozważania tego, do czego konkretnie miałoby prowadzić ich zastosowanie, to takie radykalne stanowisko może wydawać się wielu osobom nie do zaakceptowania. Stopień naszego zaangażowania w związki międzyludzkie z pewnością wykracza poza tak nakreślony schemat. Wierne podążanie za myślą Doktora Łaski wymagałoby od każdego rewizji swojego stosunku do bliźnich. Z pewnością nie wszyscy ludzie wierzący byliby do tego zdolni i nie wszyscy zgodziliby się z tym, że taka postawa jest słuszna. Sądzę, że współczesnemu chrześcijaninowi znacznie bliższe są koncepcje teocentryczne mniej radykalne.

Wybrałem Bubera jako filozofa, z którym chciałbym skontrastować Biskupa z Hippony. Jest to również myśliciel religijny. Co więcej, jest to również filozof pochodzący z tradycji monoteizmu biblijnego, w którego „systemie” (nie mniej od Augustyna trudno uchwytnym) Bóg zajmuje 
centralne miejsce. Mimo to sposób, w jaki rozumie więzi międzyludzkie i etykę postępowania wobec bliźnich, różni się znacznie od Augustyna.

Dla Bubera relacja $\mathrm{z}$ drugim człowiekiem, jakkolwiek by ona nie była głęboka i wyjątkowa, wymaga dopełnienia. Ty Absolutne jest dopełnieniem każdego innego możliwego „ty”. Dotyczy to zarówno ludzi, jak i innych bytów, z którymi można nawiązać jakiś rodzaj kontaktu. Wprawdzie każda relacja jest wyłączna i ma na celu osobę, z którą pozostaje się w relacji, ale jednocześnie każda autentyczna relacja może stać się możliwością wejścia $\mathrm{w}$ relację z Bogiem. Jeśli dobrze rozumiem jego myśl, to na pewnym poziomie perspektywa „ja - ty” zaczyna tworzyć pewną całość. I ta całość - wszystko, co istnieje - jest przejawem Boskiego Ty i sposobem na pozostawanie z Nim w żywej relacji. Ta żywa więź różni się od tego, co często ludzie rozumieją jako religię. Można powiedzieć, że religie reprezentowane przez instytucje często (choć niekoniecznie) w miejsce postawy „ja - ty” stawiają „ja - to”. Bóg staje się tutaj rzeczą o pewnych właściwościach, przedmiotem, który się czci. Człowiek wiary pozostający w autentycznej relacji do Boga, czyni to, żyjąc nakierowanym na świat ,ja - ty”.

Można dostrzec podobieństwo z koncepcją św. Augustyna. Nakaz praktykowania miłości bliźniego jako integralnego elementu wiary wydaje się zbliżony do myśli żydowsko-niemieckiego myśliciela. Biskup z Hippony również pisze o tym, że w drugim człowieku odnajdujemy ślad Boga i dzięki miłości bliźniego możemy dążyć do Absolutu. Podkreśla, za Ewangelią, że praktykowanie miłości do Boga oznacza przykazanie miłości ludzi, a nie puste wypełnianie rytuałów. Całe stworzenie jest również dla niego znakiem Absolutu i jednocześnie drogą prowadzącą do Niego. Co więcej, obaj używają nawet podobnego zwrotu, pisząc o tym, że dzięki miłości do Boga, wszystko może żyć w Nim i w Nim znajdować swoje miejsce i wartość.

Moim zdaniem, mimo że można odnieść wrażenie, iż różnica między tymi dwoma filozofami nie jest zbyt duża, to jednak jest ona bardzo znacząca. U Bubera bowiem, i to chciałem podkreślić, biorąc go za przykład, człowiek nie jest tylko stopniem w dążeniu do Boga. Relacja z nim nie jest tylko sposobem na wielbienie Absolutu. 
W relacji do Boga bezwarunkowa wyłączność i bezwarunkowa włączność stanowią jedno. Kto wchodzi w absolutną relację, tego nie obchodzi już nic pojedynczego: rzeczy czy istoty, ziemia czy niebo; wszystko jednak zawiera się w relacji. Wejście bowiem w czystą relację to nie rezygnacja ze wszystkiego, lecz widzenie wszystkiego w Ty. Nie wyrzekanie się świata, lecz stawianie go na jego podstawie [...]. Zmysł Ty człowieka, który na podstawie relacji do pojedynczych TY, doświadcza rozczarowania związanego ze stawaniem się TO, dąży - poprzez wszystkie Ty, ale nie obok nich - do swego wiecznego Ty [...]. Ale gdy znajdzie, jego serce nie odwraca się od nich, nawet jeśli w jednym spotyka wszystko. Błogosławi cele, w których się chronił, i wszystkie, do których jeszcze zawita ${ }^{20}$.

Otóż myślę, że w tym długim cytacie zawiera się tych kilka istotnych według mnie elementów. Sądzę, że dobrze obrazują one różnice między dwoma omawianymi przeze mnie myślicielami.

Po pierwsze, więzi z innymi nie są tylko środkami do celu, jakim jest Bóg. Każdy z pojedynczych celów, z którymi człowiek jest związany, zachowuje swoją ważność. Paradoksalność, o której pisze, polega na tym, że relacja z Bogiem jest jednocześnie jedyna i niepowtarzalna, całkowicie absorbująca osobę, ale jednocześnie nie unieważnia wcześniejszych międzyludzkich (i nie tylko) związków. To, w jaki sposób jest to możliwe, nie jest tematem mojej pracy, z mojego punktu widzenia istotne jest to, że podkreśla się, iż międzyludzkie relacje mają dwoisty charakter. Są celami sami w sobie i jednocześnie sposobem, dzięki któremu można dojść do poziomu żywej więzi z Bogiem. Podobne myśli możemy znaleźć także u Emmanuela Levinasa ${ }^{21}$ i ks. Józefa Tischnera ${ }^{22}$. Nie ma tu tak ostrego przeciwstawienia relacji z Bogiem relacji z ludźmi. Czytelnicy ks. Tischnera i filozofów dialogu z pewnością będą zwracać uwagę na to, że miłość bliźniego można postrzegać nie jako potencjalną konkurencję miłości do Boga, lecz jako rodzaj duchowej drogi do

20 M. Buber, Ja i Ty. Wybór pism filozoficznych, tłum. J. Doktór, Warszawa 1992, s. 87-88.

${ }^{21}$ E. Levinas, Całość i nieskończoność. Esej o zewnętrzności, tłum. M. Kowalska, Warszawa 2002.

22 J. Tischner, Filozofia dramatu, Kraków 2006. 
niej prowadzącej. W tym ujęciu faktycznie pojawia się kategoria osoby ludzkiej. Zachowuje ona pewną wartość niezależnie od relacji ze swoim Stwórcą. Co więcej, chociaż relacja z bliźnimi może prowadzić do uznawanej za najwyższą miłości do Boga, to osiągnięcie tego punktu wcale jej nie unieważnia ani nie deprecjonuje jej autonomicznej wartości.

Na tym polega druga rzecz, którą chciałbym podkreślić. Ta filozofia nie odrzuca świata w imię Absolutu. Afirmacja życia u Bubera to coś więcej, niż tylko uznanie stworzenia za dzieło Boga i używanie go, które byłoby spełnianiem obowiązku wobec Niego. Stworzenie ma wartość samą w sobie - jest czymś dobrym. Przeciwnie niż u Augustyna, trzeba się zaangażować w doczesną rzeczywistość. Intrygujące u tego filozofa jest to, że dopiero naprawdę kochając świat i istoty w nim przebywające, możemy wejść na drogę wiary. Ponieważ dopiero to umożliwia przyjęcie perspektywy „ja - ty”, a ta ostatecznie prowadzi do Absolutu. Żeby jednak być w takim kontakcie ze światem, trzeba przestać traktować go i rozumieć wyłącznie w kategoriach używania. Używanie czegoś to zachowanie ze świata „ja - to”, a więc to, co uniemożliwia wejście w autentyczną więź. Dopiero wtedy, kiedy udaje się dostrzec w stworzeniu coś więcej niż przedmioty, które zostały stworzone do tego, żeby ich używać, można naprawdę wejść do pożądanej strefy „ja - ty”. Jak wiadomo, jednym z pierwszych przykładów, jakie Buber omawia, jest przykład drzewa - bardzo enigmatyczny i trudno by mi było powiedzieć, na czym miałaby relacja z dębem polegać, ale dobrze pokazuje zasadnicze nastawienie tej filozofii. Celem nie jest ucieczka od świata, przeciwnie - celem jest wejście z nim w stosunek wykraczający poza układ podmiot - przedmiot.

Ostatnim elementem, na który szczególnie chciałem zwrócić uwage i który tak jak i poprzednie odróżnia filozofię Bubera od św. Augustyna, jest stosunek do ,ja”. Podmiot nie rozpływa się w Absolucie. Buber pisze, że do nawiązania właściwej relacji potrzebne jest „ja”. Relacja oznacza u niego wzajemny związek między dwoma podmiotami. Co ciekawe, wzajemność dotyczy również Boga. W jakiś sposób Bóg również zyskuje coś na relacji ze swoim Stworzeniem. To oczywiście zdanie bluźniercze z perspektywy Augustyna. Tam „ja” zawdzięcza wszystko Absolutowi. 
Jest to przykład skrajnie niesymetrycznej relacji, ponieważ Bóg niczego nie zyskuje i w żaden sposób się nie wzbogaca dzięki człowiekowi. Świadczyłoby to o Jego uprzedniej niedoskonałości - skoro mógł coś otrzymać dzięki swojemu własnemu stworzeniu. Pozostawiając jednak tę zawiłą teologiczną kwestię, chciałem podkreślić, że „ja” u Bubera zostaje zachowane. Stworzenie posiada pewną wartość autonomiczną. Niezależną całkowicie od Boga. Nie oznacza to jednak, że świat stawiany jest wyżej swojego Stworzyciela. Nic podobnego. Jest to jednak, jak sądzę, przykład innego rozumowania. O ile u Augustyna jest ono oparte na skrajnej opozycji „albo-albo", albo Bóg, albo świat, to u Bubera mamy do czynienia z czymś bardziej zróżnicowanym. Przyznanie pewnej samodzielnej wartości światu, ludziom i własnemu „ja” nie oznacza od razu, że się je absolutyzuje. Bynajmniej, świat pozostaje zależny od Boga uznający Jego doskonałość i supremację. Absolut jest jak najbardziej najwyższym celem ludzkich działań i dążeń.

\section{Zakończenie}

Myśl św. Augustyna, a szczególnie jego koncepcja miłości, jest bardzo ciekawą, intrygującą i bardzo wartościową filozofią. Niemniej, trudno, moim zdaniem, czytając ją z dzisiejszej perspektywy, nie popatrzyć na nią krytycznie. Ostatecznie nie wydaje mi się przekonujące, ani nawet możliwe do zaakceptowania, tworzenie wzorców relacji międzyludzkich, w myśl których wartość drugiej osoby jest zredukowana i pomniejszona do roli środka w dążeniu do celu. Nawet jeśli ten cel jest doskonałym Bogiem, to można mieć wątpliwości, czy taka filozofia jest słuszna. Moim zdaniem nie można skonstruować $w$ ten sposób żadnej wiarygodnej filozofii faktycznie mówiącej o relacjach międzyludzkich.

$\mathrm{Na}$ koniec chciałem zwrócić uwagę na to, że dzięki takiej analizie można zaobserwować to, jak zmieniała się filozofia i wrażliwość ludzi związanych z wiarą. Koncepcja miłości św. Augustyna to - jak sądzę - jedna z najważniejszych i najciekawszych teorii takiego rodzaju. Niemniej trudno się oprzeć, moim zdaniem, krytycznej refleksji 
związanej z postulowanym przez niego stosunkiem do bliźnich. Wydaje mi się, że chcąc faktycznie skonstruować teorię podejmującą temat relacji międzyludzkich, zawsze trzeba założyć, że naszym właściwym celem jest drugi człowiek, postrzegany jako podmiot. Jak pokazuje chociażby filozofia wspomnianego przeze mnie Bubera, nie musi to prowadzić (czego obawiał się Augustyn) do absolutyzowania człowieka i umieszczania go na miejscu Boga. 